\title{
KEMAMPUAN KOMUNIKASI MATEMATIKA SMA DALAM MENYELESAIKAN SOAL CERITA PROGRAM LINEAR DITINJAU DARI KECERDASAN LINGUISTIK
}

\author{
Mohammad Nabil Nurfaizi ${ }^{1}$, Ismail ${ }^{2}$ \\ ${ }^{1,2}$ Universitas Negeri Surabaya \\ e-mail: $\underline{1}$ nabilnurfaizi@gmail.com, ${ }^{2}$ ismail@unesa.ac.id
}

\begin{abstract}
Abstrak
Komunikasi memiliki peran penting pada pembelajaran matematika. Komunikasi matematika terbagi menjadi dua yaitu lisan dan tulis. Komunikasi matematika sangat dibutuhkan ketika menyelesaikan soal cerita karena informasi pada soal cerita perlu dipahami dan dituliskan dengan benar. Kecerdasan linguistik termasuk dalam teori kecerdasan majemuk yang ditemukan oleh Howard Gardner. Tujuan dari penelitian ini adalah mendeskripsikan kemampuan komunikasi matematika siswa SMA dalam menyelesaikan soal cerita ditinjau dari kecerdasan linguistik. Metode penelitian yang digunakan dalam penelitian ini adalah deskriptif dengan pendekatan kualitatif dengan tiga subjek terpilih sesuai dengan hasil angket kecerdasan linguistik rendah, sedang, dan tinggi. Subjek terpilih melaksanakan tes soal cerita dan wawancara. Hasil penelitian ini menunjukkan bahwa siswa dengan kecerdasan linguistik tinggi mencapai seluruh indikator komunikasi matematika.Sedangkan siswa dengan kecerdasan linguistik sedang belum mencapai seluruh indikator begitu juga siswa dengan kecerdasan linguistik rendah. Penelitian ini menyarankan agar guru dapat menentukan model pembelajaran dan kegiatan pembelajaran yang cocok untuk meningkatkan kemampuan komunikasi siswa.
\end{abstract}

Kata kunci: Komunikasi Matematika, Soal Cerita, Kecerdasan Linguistik

\begin{abstract}
Metacognition plays an important role in problem-solving activities. It will help students to find what the problem is and understand how to get the solution. This study aimed at describing the student's metacognition process based on Keirsey's personality types. This research used qualitative method with descriptive approach and it was conducted involving eight students who have equal mathematical abilities and the same gender. The selected students represented Keirsey's personality types. They were carried out through two types of tests, namely the Keirsey Temperament Sorter and the Mathematics Ability Test. The result showed that each personality type could through indicators of the metacognition process. However, there are some indicator components missed. Rational and idealist student have not been able to carry out the metacognition process in the regulation stage properly. Guardian and artisan student have been able to carry out the metacognition process well. This study suggests the teacher can facilitate students in each personality type by determining the appropriate learning model, learning activities, and assessments to obtain better results.
\end{abstract}

Keywords: Mathematic Communication, Contextual Problems, and Linguistic Intelligences.

\section{Pendahuluan}

Manusia perlu adanya interaksi antar manusia yaitu komunikasi. Komunikasi merupakan hal yang sangat penting dalam kehidupan sehari-hari karena dengan berkomunikasi, informasi bisa tersampaikan tanpa ada kesalahpahaman dari penerima ataupun pemberi informasi. 
Komunikasi memiliki banyak peran dalam dunia pendidikan, salah satunya pada pembelajaran matematika. Ketika peserta didik dituntut untuk mampu berpikir dan berpendapat maka komunikasi adalah fasilitas penting dalam mengungkapkan hasil pemikiran mereka secara lisan maupun dalam bentuk tulisan [1], yang artinya komunikasi matematika tidak hanya dilakukan secara lisan saja tetapi juga komunikasi dalam tulisan. Sebagai contoh komunikasi matematika secara lisan yaitu diskusi dan menjelaskan konsep-konsep matematika sedangkan secara tulis contohnya mengungkapkan ide matematika melalui gambar/grafik, tabel, persamaan, ataupun dengan bahasa yang mudah dipahami.

Banyak sekali penyebab rendahnya kemampuan komunikasi matematika siswa. Salah satunya adalah dikarenakan siswa kurang bisa mengkomunikasikan ide-ide matematika dalam pembelajaran matematika [2]. Kemudian Utami (2015) menyatakan bahwa kemampuan komunikasi matematika siswa masih belum optimal [3]. Proses belajar yang monoton dapat menimbulkan dampak negatif kepada siswa. Misalkan kurangnya kemampuan pemahaman konsep matematika yang dimiliki siswa, kenyataannya kemampuan untuk memahami suatu permasalahan matematika kemudian mengubahnya kedalam bentuk simbol-simbol matematika merupakan kemampuan yang diperlukan dalam komunikasi matematika [4]. Komunikasi matematika tulis dan lisan merupakan bagian penting dalam pembelajaran matematika karena melalui komunikasi matematika siswa belajar memahami soal yang diberikan oleh guru kemudian diungkapkan dalam bentuk tulisan. Komunikasi saat pembelajaran matematika dapat terjadi antara guru dan siswa, siswa dan siswa, ataupun siswa dengan media yang digunakan, seperti buku atau video edukasi. Melalui komunikasi ide dapat dicerminkan, diperbaiki, didiskusikan, dan dikembangkan. Saat siswa berbicara, menulis, membaca, dan mendengarkan materi matematika, mereka memperoleh keuntungan ganda yaitu; mereka berkomunikasi untuk mempelajari matematika, dan mereka belajar untuk berkomunikasi secara matematika [1].

Kemampuan komunikasi matematika siswa yang rendah, tentunya dapat ditingkatkan. Salah satu cara untuk komunikasi matematika tulis yaitu siswa dibiasakan menyelesaikan soal secara terurut dan jelas, tidak tergesa-gesa agar tidak ada proses yang terlewatkan. Sedangkan kemampuan komunikasi matematika secara lisan dapat ditingkatkan dengan aktif berkomunikasi dengan siswa agar siswa terbiasa menjawab pertanyaan dari guru dengan jelas. Penting bagi guru untuk mengetahui kemampuan komunikasi matematika peserta didik dalam proses belajaran matematika. Sesuai dengan permendiknas no. 21 tahun 2016 tentang standar isi pendidikan dasar dan menengah yaitu memiliki kemampuan mengkomunikasikan gagasan matematika dengan jelas dan efektif [5]. Dalam NCTM terdapat empat standar komunikasi, yaitu (1) Mengorganisasikan dan menggabungkan pemikiran matematika siswa melalui komunikasi; (2) Mengekspresikan ide-ide matematika dengan tepat menggunakan bahasa matematika; (3) Mengomunikasikan pemikiran matematika siswa secara masuk akal dan jelas kepada teman sebaya, guru, dan lainnya; (4) Menganalisis dan mengevaluasi pemikiran dan strategi matematika lain [1];

Komunikasi matematika sangat dibutuhkan ketika menyelesaikan soal cerita karena informasi pada soal cerita perlu dipahami dan dituliskan dengan benar. Sesuai dengan pernyataan Rahardjo dan Astuti, soal cerita matematika adalah soal matematika yang terkait dengan kehidupan sehari-hari untuk dicari penyelesaiannya menggunakan kalimat matematika yang memuat bilangan, operasi hitung dan relasi[6]. Soal cerita adalah soal yang berbentuk cerita serta berhubungan dengan kehidupan sehari-hari [7]. Dalam proses pengerjaan soal cerita, siswa tidak hanya membaca kemudian menyelesaikan soal tersebut, tetapi siswa perlu memahami informasi yang ada pada soal agar dapat menentukan strategi apa yang harus digunakan untuk menyelesaikan soal. Proses penyelesaian dan solusi dari soal haruslah dikomunikasikan dengan jelas menggunakan bahasa sendiri.

Multiple Intelligences dalam bahasa Indonesia diterjemahkan sebagai kecerdasan majemuk atau kecerdasan ganda. Teori ini dikemukakan oleh Howard Gardner, psikolog dari Harvard. Gardner memandang kecerdasan manusia melalui: (1) kemampuan menyelesaikan masalah yang terjadi dalam kehidupan sehari-hari, (2) kemampuan manusia untuk menghasilkan persoalan-persoalan baru untuk diselesaikan, (3) kemampuan untuk menciptakan sesuatu atau 
menawarkan jasa yang akan menimbulkan penghargaan untuk salah satu budaya. Kecerdasan menurut Gardner diartikan sebagai suatu kemampuan, dengan proses kelengkapannya, yang sanggup menangani kandungan masalah yang spesifik di dunia [8][9]. Kecerdasan majemuk menurut Howard Gardner ada sembilan, yaitu Verbal-Linguistic Intellegence, LogicalMathematical Intellegence, Visual-Spatial Intellegence, Bodily-Kinesthetic Intellegence, Musical-Rhytmic Intellegence, Interpersonal Intelligence, Intrapersonal Intelligence, Naturalist Intelligence, dan Existential Intellegence [9]. Dalam penilitian ini peneliti mengambil subjek sesuai tingkat Verbal-Linguistic Intellegence tinggi, sedang, dan rendah.

Kecerdasan linguistik dapat diartikan kapasitas atau kemampuan untuk menggunakan kata-kata secara efektif, baik secara lisan atau secara tulisan. Kecerdasan ini mencakup kemampuan untuk memanipulasi sintaks atau struktur bahasa, fonologi atau bunyi bahasa, semantik atau makna bahasa, dan dimensi pragmatis atau penggunaan praktis bahasa. Seseorang dengan kecerdasan linguistik biasanya memiliki keahlian, yaitu retorika (menggunakan bahasa untuk meyakinkan orang lain untuk mengambil tindakan tertentu), mnemonik (menggunakan bahasa untuk mengingat informasi), penjelasan (menggunakan bahasa untuk menginformasikan), dan metalanguage (menggunakan bahasa untuk berbicara tentang dirinya sendiri) [10]. Lwin berkata bahwa kecerdasan linguistik adalah kemampuan untuk menyusun pikiran dengan jelas dan menggunakannya secara kompeten melalui kata-kata seperti bicara, membaca, dan menulis [11]. Maka dapat disimpulkan bahwa terdapat korelasi antara kecerdasan linguistik dan kemampuan komunikasi matematika baik secara lisan atau tulisan.

Berdasarkan pernyataan-pernyataan di atas, pertanyaan penelitian yang terbentuk adalah "Bagaimana kemampuan komunikasi matematika siswa SMA dengan kecerdasan linguistik tinggi, sedang, dan rendah dalam menyelesaikan soal cerita?". Berdasarkan pertanyaan tersebut tujuan peneliti melakukan penelitian ini adalah untuk mendeskripsikan kemampuan komunikasi matematika siswa SMA dalam menyelesaikan soal cerita ditinjau dari kecerdasan linguistik siswa.

\section{Metode Penelitian}

\subsection{Jenis dan Subjek Penelitian}

Peneliti menggunakan metode penelitian deskriptif dengan pendekatan kualitatif. Subjek penelitian yang diambil dalam penelitian ini ada tiga subjek dengan kriteria satu subjek dengan skor Kecerdasan Verbal Linguistik tinggi, satu subjek dengan skor Kecerdasan Verbal Liguistik sedang, dan satu subjek dengan skor Kecerdasan Verbal Liguistik rendah. Penelitian ini tidak memperhatikan jenis kelamin, sesuai dengan pernyataan Iyan dan Reza (2014) tidak ada perbedaan kecerdasan linguistik antara siswa laki-laki dengan perempuan [12].

\subsection{Prosedur Penelitian}

Siswa melaksanakan tes kecerdasan majemuk terlebih dahulu yang kemudian diklasifikasikan sesuai kriteria peneliti. Setelah peneliti menentukan subjek penelitian, langkah selanjutnya subjek menyeselesaikan soal cerita yang merupakan instrumen penelitian. Kemudian peneliti melakukan wawancara pada subjek. Dalam penelitian ini data yang akan diperoleh yaitu data hasil tes kecerdasan majemuk, data hasil penyelesaian soal cerita, dan data hasil wawancara. Data hasil tes kecerdasan majemuk digunakan untuk menentukan subjek, angket kecerdasan majemuk yang digunakan peneliti diadopsi dari Yanti [13]. Angket tersebut terdiri dari 108 pernyataan dengan jumlah 12 pernyataan mewakili setiap kecerdasan. Peneliti akan menghitung skor tes kecerdasan majemuk siswa kemudian dipilih tiga siswa yang sesuai dengan kriteria yang telah ditetapkan peneliti. Berikut tabel tingkatan rendah, sedang, dan tinggi pada kecerdasan majemuk.

Tabel 1. Tingkatan Kecerdasan Linguistik

\begin{tabular}{cc}
\hline Tingkat & Skor \\
\hline Tinggi & skor angket $\geq 36$ \\
\hline
\end{tabular}




\begin{tabular}{cc}
\hline Tingkat & Skor \\
\hline Sedang & $24<$ skor angket $<36$ \\
Rendah & $12 \leq$ skor angket $\leq 24$ \\
\hline
\end{tabular}

Data hasil penyelesaian soal cerita dan wawancara digunakan untuk mendeskripsikan kemampuan komunukasi matematika siswa baik tulis maupun lisan. Soal cerita yang digunakan peneliti adalah soal UNBK Matematika IPA tahun 2019. Berikut indikator komunikasi matematika yang telah dibuat oleh peneliti.

Tabel 2. Indikator Kemampuan Komunikasi Matematika

\begin{tabular}{|c|c|c|}
\hline \multirow{2}{*}{$\begin{array}{c}\text { Standar Komunikasi } \\
\text { Matematika Menurut } \\
\text { NCTM }\end{array}$} & \multicolumn{2}{|c|}{ Indikator Komunikasi Matematika } \\
\hline & Tulis & Lisan \\
\hline \multirow[t]{2}{*}{$\begin{array}{l}\text { Mengorganisasikan dan } \\
\text { menggabungkan } \\
\text { pemikiran matematika } \\
\text { siswa melalui komunikasi }\end{array}$} & $\begin{array}{l}\text { Mampu menuliskan informasi } \\
\text { yang diketahui dan ditanyakan } \\
\text { secara jelas pada soal program } \\
\text { linear }\end{array}$ & \begin{tabular}{lrr} 
Mampu & \multicolumn{2}{r}{ menjelaskan } \\
maksud dari & soal \\
program linear & yang \\
diberikan & menggunakan \\
bahasa sendiri & \\
\end{tabular} \\
\hline & $\begin{array}{l}\text { Mampu menentukan strategi } \\
\text { yang akan digunakan dalam } \\
\text { menyelesaikan soal dengan } \\
\text { jelas }\end{array}$ & $\begin{array}{lr}\text { Mampu menjelaskan } \\
\text { strategi yang } & \text { akan } \\
\text { digunakan } & \\
\text { menggunakan } & \text { bahasa } \\
\text { sendiri } & \end{array}$ \\
\hline $\begin{array}{l}\text { Mengekspresikan ide-ide } \\
\text { matematika dengan tepat } \\
\text { menggunakan bahasa } \\
\text { matematika }\end{array}$ & $\begin{array}{l}\text { Mampu membuat pemodelan } \\
\text { matematika dari soal program } \\
\text { linear menggunakan simbol- } \\
\text { simbol matematika dalam } \\
\text { bentuk tulisan ataupun gambar }\end{array}$ & $\begin{array}{l}\text { Mampu memahami dan } \\
\text { menjelaskan bahasa } \\
\text { matematika yang ada } \\
\text { pada soal program linear }\end{array}$ \\
\hline $\begin{array}{l}\text { Mengomunikasikan } \\
\text { pemikiran matematika } \\
\text { siswa secara masuk akal } \\
\text { dan jelas kepada teman } \\
\text { sebaya, guru, dan lainnya }\end{array}$ & $\begin{array}{l}\text { Mampu menuliskan proses } \\
\text { penyelesaian serta membuat } \\
\text { kesimpulan penyelesaian soal } \\
\text { program linear secara urut dan } \\
\text { jelas }\end{array}$ & $\begin{array}{l}\text { Mampu menjelaskan } \\
\text { proses penyelesaian dari } \\
\text { soal program linear } \\
\text { secara urut dan masuk } \\
\text { akal }\end{array}$ \\
\hline 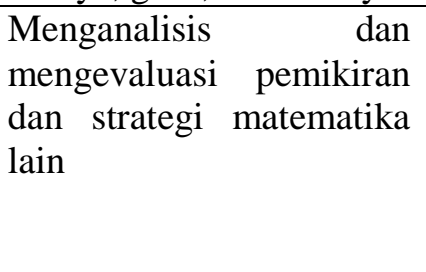 & $\begin{array}{lrr}\text { Mampu menganalisis dan } \\
\text { mengevaluasi } & \text { strategi yang } \\
\text { digunakan } & \text { kemudian } \\
\text { menuliskan strategi lain dalam } \\
\text { menyelesaikan } & \text { soal program } \\
\text { linear } & \end{array}$ & \begin{tabular}{lcr} 
Mampu & \multicolumn{2}{r}{ menjelaskan } \\
hasil analisis & dan \\
evaluasi & strategi lain \\
untuk mengerjakan soal
\end{tabular} \\
\hline
\end{tabular}

\section{Hasil dan Pembahasan}

Peneliti telah memilih 3 subjek dari 20 siswa yang mengisi angket kecerdasan majemuk, sebagai berikut.

Tabel 3. Subjek Penelitian

\begin{tabular}{|c|c|c|c|}
\hline \multirow{2}{*}{ No } & \multirow{2}{*}{ Inisial Siswa } & \multicolumn{2}{|c|}{ Linguistik } \\
\cline { 3 - 4 } & & Skor & Kategori \\
\hline 1 & RAAM & 36 & Tinggi \\
\hline 2 & APH & 31 & Sedang \\
\hline 3 & DNRP & 24 & Rendah \\
\hline
\end{tabular}

\subsection{Hasil}




\section{Hasil dan Analisis Tes Kemampuan Komunikasi Matematika Tulis Subjek Linguistik Tinggi (SLT)}

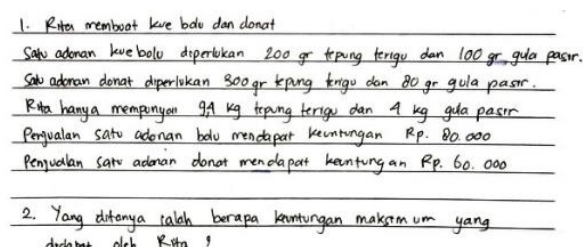

Gambar 1. SLT Menuliskan Informasi pada Soal

Berdasarkan gambar 1SLT mampu menuliskan informasi yang ada pada soal dengan lengkap dan benar. Penulisan informasi juga sangat jelas dan informatif. Kemudian penulisan kalimat tanya yang ditulis oleh subjek sudah tepat hanya saja kalimat yang digunakan kurang efektif, karena tidak langsung dimulai dengan kata tanya.

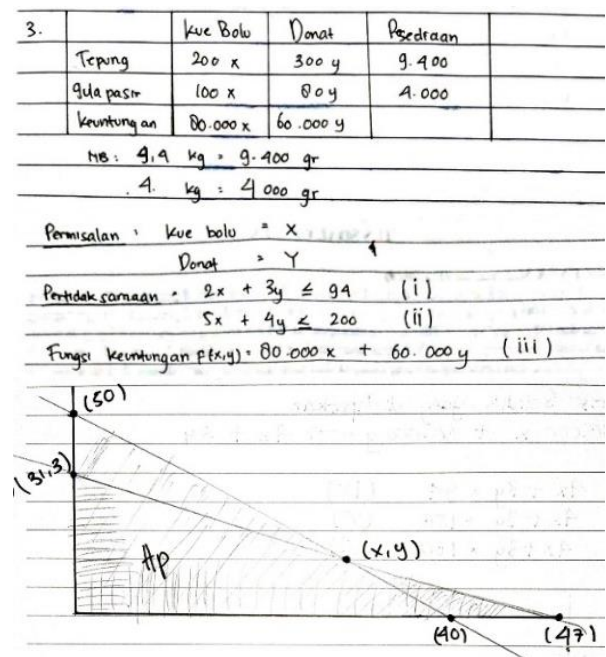

Gambar 2. SLT Membuat Permisalan, Pertidaksamaan, dan Koordinat Kartesius

Berdasarkan gambar 2, SLT dapat membuat permisalan dengan benar serta membuat tabel yang berisi informasi singkat yang ada pada soal. Pertidaksamaan yang dituliskan sudah sesuai dengan informasi yang ada pada soal meskipun ada informasi yang terlewat untuk dituliskan. Subjek juga menggambar koordinat kartesius serta menentukan himpunan penyelesaian sesuai dengan informasi yang ada pada soal dengan benar dan jelas.

$$
\text { 4. U) titik pojok, karma brasanya sama guru disckelah }
$$

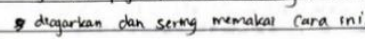

Gambar 3. SLT Menentukan Strategi yang Akan Digunakan

Berdasarkan gambar 3, SLT mampu menentukan strategi yang akan digunakan untuk menyelesaikan soal namun belum mampu menjelaskan strategi pengerjaan dengan jelas, karena alasan menggunakan cara tersebut tidak menjelaskan pendapat subjek tentang strategi tersebut. 


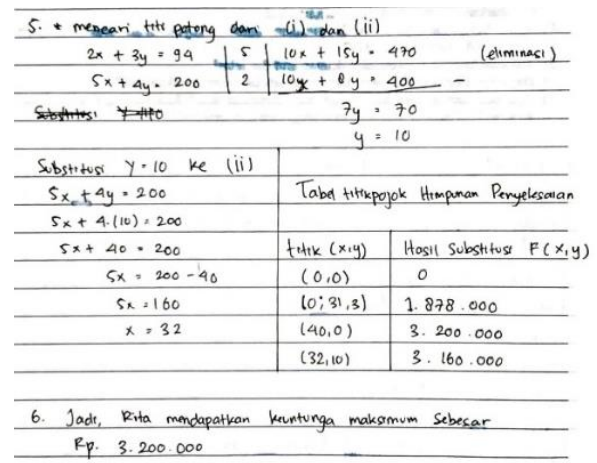

Gambar 4. SLT Menuliskan Proses Penyelesaian

Berdasarkan gamar 4, SLT mampu menuliskan proses penyelesaian dengan urut dan jelas sehingga mudah dipahami. Alasan dari penyelesaian juga dituliskan sehingga lebih informatif. Kesimpulan yang dituliskan oleh subjek juga tepat dan tidak rumit, sehingga mudah untuk dimengerti.

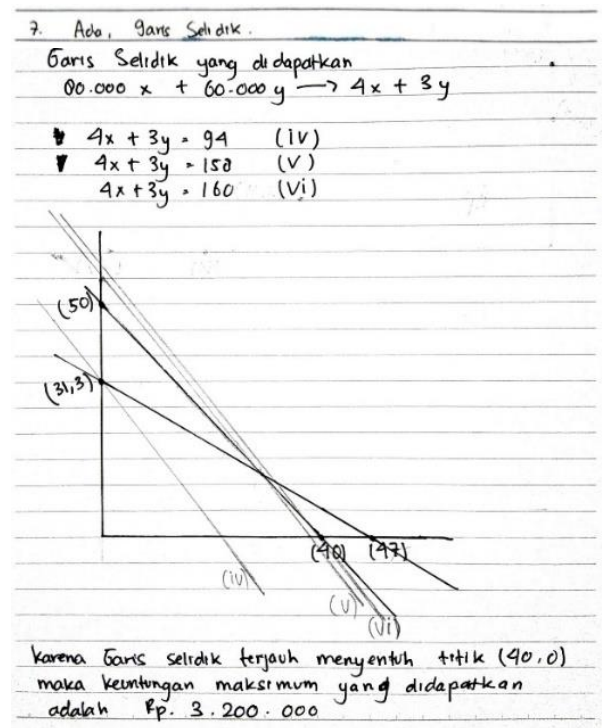

Gambar 5. SLT Menuliskan Strategi Penyelesaian Lain

SLT mampu menemukan serta menuliskan proses penyelesaian soal menggunakan strategi lain dengan benar dan terperinci sehingga mudah untuk dipahami.

\section{Hasil dan Analisis Tes Kemampuan Komunikasi Matematika Lisan Subjek Linguistik} Tinggi (SLT)

Tabel 4. Wawancara SLT dalam Menjelaskan Maksud Soal

\begin{tabular}{|l|l|l|}
\hline Kode & & \multicolumn{1}{c|}{ Wawancara } \\
\hline P & $:$ & Apa saja informasi yang anda dapat setelah membaca soal? \\
\hline SLT & $:$ & $\begin{array}{l}\text { Jadi informasi yang Saya dapatkan yaitu Rita membuat kue bolu dan } \\
\text { donat. Satu adonan kue bolu diperlukan 200 gram tepung terigu dan }\end{array}$ \\
& $\begin{array}{l}\text { 100 gram gula pasir, sedangkan satu adonan donat diperlukan 300 } \\
\text { gram tepung terigu dan 80 gram gula pasir, namun rita hanya } \\
\text { mampunyai 9,4 kilogram tepung terigu dan 4 kilogram gula pasir. } \\
\text { Dari penjualan tersebut rita mendapatkan keuntungan 80000 rupiah } \\
\text { untuk penjualan 1 adonan kue bolu dan mendapatkan keuntungan } \\
\text { 60000 rupiah untuk penjualan 1 adonan donat }\end{array}$ \\
\hline
\end{tabular}




\begin{tabular}{|l|l|l|}
\hline \multicolumn{1}{|c|}{ Kode } & & \multicolumn{1}{c|}{ Wawancara } \\
\hline P & $:$ & Oke selanjutnya, termasuk pada materi apa soal tersebut? \\
\hline SLT & $:$ & Soal ini termasuk pada materi program linear \\
\hline
\end{tabular}

Bedasarkan tabel 4, SLT mampu menjelaskan informasi yang ada pada soal secara terperinci dan teratur serta menggunakan bahasa yang mudah dipahami. Semua informasi yang ada pada soal tidak terlewat sedikitpun, termasuk satuan-satuan yang ada pada soal tidak lupa disebutkan. Subjek menjelaskan tanpa ada rasa ragu atau kebingungan. Penjelasan yang disampaikan oleh subjek tidak sepotong-sepotong, subjek dengan mudah menggunakan kata penghubung yang membuat informasi semakin jelas dan mudah dipahami.

Tabel 5. Wawancara SLT dalam Menjelaskan Bahasa Matematika pada Soal

\begin{tabular}{|l|l|l|}
\hline Kode & \multicolumn{1}{|c|}{ Wawancara } \\
\hline P & $:$ & $\begin{array}{l}\text { Kemudian dari informasi yang ada pada soal, apakah ada yang bisa } \\
\text { diubah menjadi bahasa matematika? }\end{array}$ \\
\hline SLT & $:$ & $\begin{array}{l}\text { Ada yang bisa diubah. } \\
\text { Dipermisalkan, seperti misalkan kue bolu dimisalkan menjadi } x \text { lalu } \\
\text { donat dimisalkan menjadi } y, \text { terus ada pertidaksamaan jumlah tepung } \\
\text { terigu dan gula pasir untuk setiap adonan, kalau yang tepung terigu } \\
\text { itu 2x ditambah 3y kurang dari sama dengan 94 terus kalau yang gula } \\
\text { pasir itu 5x tambah 4y kurang dari sama dengan 200 pertidaksamaan } \\
\text { itu sudah disederhanakan, terus habis itu fungsi keuntungan bolu dan } \\
\text { donat yaitu 80000x ditambah 60000y. Sudah itu aja }\end{array}$ \\
\hline
\end{tabular}

Berdasarkan tabel 5, SLT mengetahui bahwa terdapat informasi pada soal yang dapat diubah menjadi bahasa matematika. Subjek dapat menjelaskan informasi pada soal yang dapat dipermisalkan dengan benar dan mudah dipahami. Subjek juga membuat pertidaksamaan melalui informasi yang ada pada soal dengan penjelasan yang benar termasuk pada penyebutan simbol yang ada pada pertidaksamaan yang dibuat oleh subjek. Subjek juga tidak lupa memberi informasi jika ada angka yang disederhanakan, sehingga tidak membuat kebingungan.

Tabel 6. Wawancara SLT dalam Menjelaskan Strategi yang Digunakan

\begin{tabular}{|l|l|l|}
\hline Kode & & \multicolumn{1}{|c|}{ Wawancara } \\
\hline P & $:$ & Strategi apa yang Anda gunakan untuk menyelesaikan soal? \\
\hline SLT & $:$ & Saya menggunakan strategi uji titik pojok \\
\hline P & $:$ & Jelaskan secara singkat dan jelas langkah-langkah strategi tersebut \\
\hline SLT & $:$ & $\begin{array}{l}\text { Langkah-langkahnya yang pertama membuat permisalan, setelah } \\
\text { membuat permisalan kita membuat pertidaksamaannya, habis itu } \\
\text { masuk membuat persamaan fungsi keuntungan, terus habis itu } \\
\text { digambar koordinat kartesiusnya terus dicari himpunan penyelesaian } \\
\text { atau hp-nya, habis itu mencari titik potong dari pertidaksamaan yang } \\
\text { diketahui, setelah itu kalau sudah ketemu titik potongnya, semua titik } \\
\text { pojoknya dimasukin ke tabel titik pojok himpunan penyelesaian terus } \\
\text { dicari nilai paling tinggi dari hasil subtitusi titik tersebut }\end{array}$ \\
\hline
\end{tabular}

Berdasarkan tabel 6, SLT mampu menjelaskan langkah-langkah strategi yang akan digunakan dengan urut dan benar. Subjek juga menjelaskan dengan lancar. Subjek tidak terlihat kebingungan dalam menjelaskan langkah-langkah dari strategi yang akan digunakan.

Tabel 7. Wawancara SLT dalam Menjelaskan Proses Penyelesaian Soal

\begin{tabular}{|l|l|l|}
\hline Kode & & \multicolumn{1}{c|}{ Wawancara } \\
\hline $\mathrm{P}$ & $:$ & $\begin{array}{l}\text { Apakah proses penyelesaian yang Anda kerjakan sesuai dengan } \\
\text { strategi yang Anda gunakan? }\end{array}$ \\
\hline SLT & $:$ & Iya sudah sesuai \\
\hline
\end{tabular}




\begin{tabular}{|l|l|l|}
\hline Kode & & \multicolumn{1}{|c|}{ Wawancara } \\
\hline P & $:$ & Jelaskan setiap langkah-langkahnya \\
\hline SLT & $:$ & $\begin{array}{l}\text { Pertama tadi ada permisalan, kita membuat permisalan dari kue bolu } \\
\text { dan donat dimisalkan menjadi } x \text { dan y, setelah itu kita masuk ke- } \\
\text { pertidaksamaan kedua adonan tersebut yang sudah disederhanakan } \\
\text { seperti tepung terigu dijadiin 2x ditambah 3y kurang dari sama } \\
\text { dengan 94 kalo yang gula pasir 5x tambah 4y kurang dari sama } \\
\text { dengan 200 habis itu masuk ke fungsi keuntungan kedua adonan itu } \\
\text { yang bolu 80000x tambah donatnya 60000y terus kita gambar } \\
\text { koordinat kartesiusnya lalu mencari himpunan penyelesaiannya, } \\
\text { setelah itu kita mencari titik potong dari pertidaksamaan 1 dan 2 } \\
\text { dengan cara eliminasi sudah ketemu y-nya sama dengan 10 kita } \\
\text { subtitusikan y-nya ke persamaan kedua terus ketemu } x \text {-nya sama } \\
\text { dengan 32 habis itu setelah ketemu y sama } x \text { kita buat tabel titik } \\
\text { pojok himpunan penyelesaiannya dari titik-titik yang membatasi } \\
\text { himpunan penyelesaian yaitu (0, 0) (0, 31,3) (40, 0) sama (32, 10) } \\
\text { hasil subtitusinya yang paling tinggi ada 3200000 dari titik (40,0) }\end{array}$ \\
\hline P & $:$ & Jadi 3200000 itu apanya? \\
\hline SLT & $:$ & Keuntungan maksimumnya \\
\hline
\end{tabular}

Berdasaran tabel 7, SLT mampu menjelaskan proses penyelesaian secara urut dan jelas sesuai dengan langkah-langkah dari strategi yang digunakan. Subjek menjelaskan setiap langkah-langkahnya dengan tenang dan lancar. Informasi yang disampaikan juga tidak sepotong-sepotong serta penyebutan simbol matematika yang benar. Setiap langkah-langkah penyelesaian juga diberi alasan oleh subjek sehingga sangat mudah dimengerti.

Tabel 8. Wawancara SLT dalam Menjelaskan Hasil Analisis dan Evaluasi Strategi Lain

\begin{tabular}{|l|l|l|}
\hline Kode & \multicolumn{1}{|c|}{ Wawancara } \\
\hline P & $:$ & $\begin{array}{l}\text { Apakah menurut Anda strategi yang Anda gunakan merupakan } \\
\text { strategi paling tepat dan mudah? }\end{array}$ \\
\hline SLT & $: \begin{array}{l}\text { Iya, karena menurut Saya strategi ini sangat objektif dan disekolah } \\
\text { juga Saya terbiasa menggunakan cara ini jadi Saya mengerjakannya } \\
\text { dengan mudah }\end{array}$ \\
\hline P & $:$ Apakah Anda menemukan strategi lain untuk menyelesaikan soal? \\
\hline SLT & $:$ & $\begin{array}{l}\text { Iya Saya tahu strategi lain. } \\
\text { Metode garis selidik }\end{array}$ \\
\hline P & $:$ & $\begin{array}{l}\text { Setelah menyelesaikan dengan metode garis selidik tersebut, Apakah } \\
\text { lebih cepat dan mudah dari pada uji titik pojok tadi? }\end{array}$ \\
\hline SLT & $: \begin{array}{l}\text { Kalau menurut Saya garis selidik ini lebih cepat tapi kalo lebih } \\
\text { mudah, enakan pakai uji titik pojok, karena kalau garis selidik ini } \\
\text { lebih memakan waktu karena harus menggeser-geser penggaris gitu } \\
\text { tapi kalo uji titik pojok itu lebih efektif dan pasti kalo garis selidik } \\
\text { lebih cepet aja gitu }\end{array}$ \\
\hline
\end{tabular}

Berdasarkan tabel 8, SLT mampu menjelaskan alasan menggunakan strategi yang digunakan dalam menyelesaikan soal dengan pendapat yang bagus. Subjek juga mampu menganalisis dan mengevaluasi strategi lain sehingga subjek dapat menjelaskan kekurangan serta kelebihan dari dua strategi yang telah subjek gunakan untuk menyelesaikan soal.

Hasil dan Analisis Tes Kemampuan Komunikasi Matematika Tulis Subjek Linguistik Sedang (SLS) 
Berdasarkan gambar 6, SLS masih kurang dalam menuliskan informasi yang ada pada soal karena informasi yang dituliskan tidak lengkap dan tidak teratur. Penulisan kalimat tanya yang ditulis oleh subjek sudah tepat.

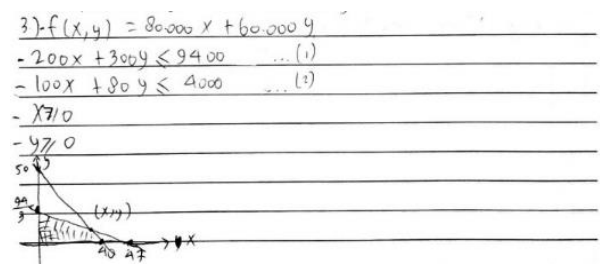

Gambar 7. SLS Membuat Permisalan, Pertidaksamaan, dan Koordinat Kartesius

Berdasarkan gambar 7, SLS tidak membuat permisalan dari informasi yang ada pada soal. Subjek sudah menuliskan pertidaksamaan sesuai dengan informasi yang ada pada soal. Subjek juga menggambar koordinat kartesius serta menentukan himpunan penyelesaian sesuai dengan informasi yang ada pada soal dengan benar meskipun kurang rapi.

SLS dalam menentukan strategi yang akan digunakan dalam menyelesaikan soal dengan jelas. SLS mampu menentukan strategi pengerjaan dengan benar namun subjek belum mampu menjelaskan alasan menggunakan strategi tersebut dengan jelas, karena alasan yang dituliskan tidak menjelaskan alasan subjek menggunakan strategi tersebut. Sama halnya dengan SLT.

SLS dalam menuliskan proses penyelesaian serta membuat kesimpulan penyelesaian soal program linear secara urut dan jelas. SLS mampu menuliskan proses penyelesaian dengan urut dan jelas. Kesimpulan yang dituliskan oleh subjek juga tepat dan tidak rumit, sehingga mudah untuk dimengerti.

SLS dalam menganalisis dan mengevaluasi strategi yang digunakan kemudian menuliskan strategi lain dalam menyelesaikan soal program linear. SLS mampu menemukan strategi lain yang dapat digunakan untuk menyelesaikan soal tersebut. Subjek juga mampu menuliskan proses penyelesaian dengan urut dan dapat dipahami.

\section{Hasil dan Analisis Tes Kemampuan Komunikasi Matematika Lisan Subjek Linguistik Sedang (SLS)}

SLS dalam menjelaskan maksud dari soal program linear yang diberikan menggunakan bahasa sendiri SLS mampu menjelaskan informasi yang ada pada soal dengan benar, meskipun masih ada beberapa informasi yang tidak dijelaskan misalkan satuan berat yang ada pada soal. Saat subjek menjelaskan informasi yang ada pada soal masih terjadi kesalahan pembacaan, namun informasi yang disampaikan sudah benar.

SLS dalam memahami dan menjelaskan bahasa matematika yang ada pada soal program linear. SLS mampu memahami dan menjelaskan bahasa matematika yang ada pada soal, hanya saja alasan yang disebutkan oleh subjek rumit dan sulit untuk dimengerti. Subjek juga mampu menyebutkan simbol pertidaksamaan dengan benar.

SLS dalam menjelaskan strategi yang akan digunakan menggunakan bahasa sendiri. SLS kurang mampu menjelaskan strategi yang akan digunakan dengan jelas, karena penjelasan yang disampaikan oleh subjek terlalu singkat dan rumit, akibatnya informasinya kurang jelas. Masih ada penjelasan dari subjek yang sulit dapat dipahami dan kurang lengkap.

SLS dalam menjelaskan proses penyelesaian dari soal program linear secara urut dan masuk akal. SLS mampu menjelaskan proses penyelesaian dengan urut dan jelas, tetapi beberapa informasi masih tidak dijelaskan oleh subjek sehingga kurang lengkap. Penjelasan informasi yang subjek sampaikan juga sudah benar termasuk pada penyebutan simbol pertidaksamaan. Subjek juga langsung menentukan kesimpulan sebelum ditanyakan oleh peneliti.

SLS dalam menjelaskan hasil analisis dan evaluasi strategi lain untuk mengerjakan soal. SLS masih kurang dalam menjelaskan hasil analisis dan evaluasi strategi lain untuk 
menyelesaikan soal, karena subjek tidak menjelaskan secara terperinci hasil analisis dan evaluasi dari strategi lain yang digunakan subjek.

\section{Hasil dan Analisis Tes Komunikasi Matematika Tulis Subjek Linguistik Rendah (SLR) \\ 1) Kue bolu, donat, tepung terigu, gula pasir, Keuntungan \\ 1 adonan bolu $R_{p} .80 .000,1$ adonan donat $R_{p} .60 .000$ \\ 2) Berapa keuntungan maksimum yang didapatkan Rita?}

Gambar 8. SLR Menuliskan Informasi pada Soal

Berdasarkan gambar 8, SLR masih kurang dalam menuliskan informasi yang ada pada soal karena informasi yang dituliskan tidak lengkap dan tidak teratur. Penulisan kalimat tanya yang ditulis oleh subjek sudah tepat.

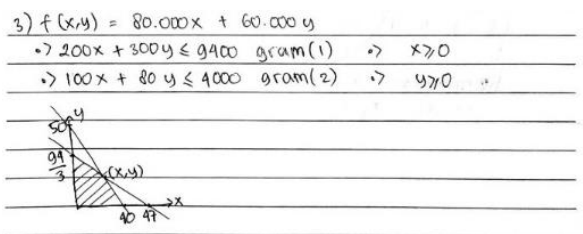

Gambar 9. SLR Membuat Permisalan, Pertidaksamaan, dan Koordinat Kartesius

Berdasarkan gambar 9, SLR tidak membuat permisalan dari informasi yang ada pada soal. Subjek sudah menuliskan pertidaksamaan sesuai dengan informasi yang ada pada soal dengan lengkap namun masih terdapat kesalahan penulisan pada pertidaksamaan yang dibuat oleh subjek. Koordinat kartesius yang digambar oleh subjek sangat jelas dan dapat dipahami.

SLR dalam menentukan strategi yang akan digunakan dalam menyelesaikan soal dengan jelas. SLR sama dengan SLT dan SLS, yaitu mampu menentukan strategi yang akan digunakan untuk menyelesaikan soal namun belum mampu menjelaskan strategi pengerjaan dengan jelas, karena alasan menggunakan cara tersebut tidak menjelaskan pendapat subjek tentang strategi tersebut.

SLR dalam menuliskan proses penyelesaian serta membuat kesimpulan penyelesaian soal program linear secara urut dan jelas. SLR mampu menuliskan proses penyelesaian dengan urut dan jelas. Kesimpulan yang dituliskan juga sudah tepat, sehingga mudah untuk dimengerti.

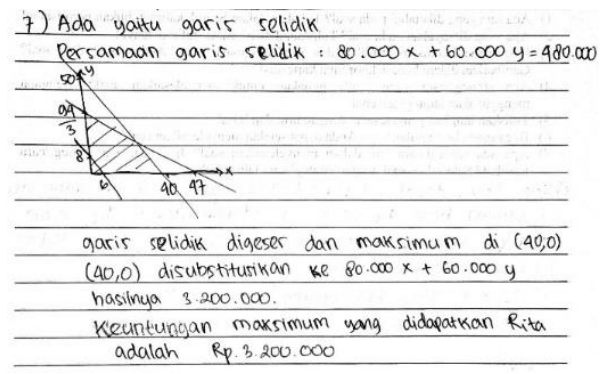

Gambar 10. SLR Menuliskan Strategi Penyelesaian Lain

Berdasarkan gambar 10, SLR mampu menemukan strategi lain yang dapat digunakan untuk menyelesaikan soal tersebut, hanya saja subjek menuliskan proses penyelesaian kurang teratur.

\section{Hasil dan Analisis Tes Kemampuan Komunikasi Matematika Lisan Subjek Linguistik Rendah (SLR)}

SLR dalam menjelaskan maksud dari soal program linear yang diberikan menggunakan bahasa sendiri. SLR mampu menjelaskan informasi yang ada pada soal dengan benar dan jelas meskipun ada sedikit informasi yang terlewat, tetapi sudah disebutkan setelah subjek melihat kembali soal yang diberikan. Penjelasan subjek dapat dipahami, namun terdapat pengulangan kata yang terdengar rumit. Subjek juga sedikit terbata-bata saat menjelaskan informasi yang ada 
pada soal. SLR dalam memahami dan menjelaskan bahasa matematika yang ada pada soal program linear. SLR masih kurang dalam memahami dan menjelaskan bahasa matematika yang ada pada soal, karena subjek salah dalam menyebutkan simbol pertidaksamaan yang ada pada soal. subjek masih bingung dalam pemilihan kalimat penjelasan sehingga saat menjelaskan subjek sesekali berhenti untuk memikirkan kalimat yang akan disampaikan.

SLR dalam menjelaskan strategi yang akan digunakan menggunakan bahasa sendiri. SLR masih kurang dalam menjelaskan strategi yang akan digunakan oleh subjek, karena subjek masih salah menyebutkan langkah-langkah pada soal kemudian penjelasan dari subjek singkat namun membingungkan. SLR dalam menjelaskan proses penyelesaian dari soal program linear secara urut dan masuk akal. SLR cukup mampu menjelaskan proses penyelesaian dari soal dengan benar, hanya saja masih ada kesalahan dalam menyebutkan simbol pertidaksamaan. Penjelasan dari subjek juga singkat sehingga informasi proses penyelesaian masih kurang lengkap. Subjek juga kurang lancar saat menjelaskan proses penyelesaiannya. SLR dalam menjelaskan hasil analisis dan evaluasi strategi lain untuk mengerjakan soal. SLR tidak menjelaskan hasil analisis dan evaluasi strategi lain yang digunakan untuk menyelesaikan soal. Subjek hanya memberi alasan pribadi, bukan hasil analisis dan evaluasi dari strategi-strategi yang digunakaan untuk menyelesaikan soal.

\subsection{Pembahasan}

\section{Kemampuan Komunikasi Matematika Tulis Subjek dengan Kecerdasan Linguistik Tinggi (SLT)}

SLT mampu menuliskan informasi yang ada pada soal dengan lengkap dan benar. Kemudian penulisan kalimat tanya yang ditulis oleh subjek sudah tepat hanya saja kalimat yang digunakan kurang efektif. Sejalan dengan perkataan Laily yaitu subjek dengan kecerdasan linguistik tinggi mampu menuliskan dan mengemukakan informasi-informasi yang terdapat dalam masalah secara lengkap, jelas dan tepat [14]. Subjek dapat membuat permisalan dengan benar serta pertidaksamaan yang dituliskan sudah sesuai dengan informasi yang ada pada soal. Subjek juga menggambar koordinat kartesius serta menentukan himpunan penyelesaian sesuai dengan informasi yang ada pada soal dengan benar dan jelas. Sejalan dengan perkataan Rahmawati, subjek dengan kecerdasan linguistik tinggi mampu membuat model matematika dengan membuat permisalannya terlebih dahulu [15]. Subjek belum mampu menentukan strategi pengerjaan dengan benar, karena alasan menggunakan cara tersebut tidak menjelaskan pendapat subjek tentang strategi tersebut. Namun subjek benar dalam menentukan strategi yang akan digunakan untuk menyelesaikan soal. Subjek mampu menuliskan proses penyelesaian dengan urut dan jelas. Kesimpulan yang dituliskan oleh subjek juga tepat dan mudah untuk dimengerti, sama seperti kata Nur laili, subjek dengan kecerdasan linguistik kategori tinggi mampu menyajikan hasil dan menjelaskan kesimpulan yang diperoleh dengan baik [16]. Subjek dengan kecerdasan linguistik tinggi mampu menemukan serta menuliskan proses penyelesaian soal menggunakan strategi lain dengan benar dan terperinci.

\section{Kemampuan Komunikasi Matematika Lisan Subjek dengan Kecerdasan Linguistik Tinggi (SLT)}

Subjek mampu menjelaskan maksud dari soal menggunakan bahasa yang mudah dipahami. Semua informasi yang ada pada soal tidak terlewat sedikitpun. Subjek menjelaskan tanpa kebingungan. Sejalan dengan penjelasan dari Laily subjek yang memiliki kecerdasan linguistik tinggi mampu memahami masalah dengan lancar dan mampu mengutarakan dengan jelas pendapatnya [14]. Subjek mampu memahami dan menjelaskan bahasa matematika yang ada pada soal serta menjelaskan permisalan yang dibuat dengan benar. Subjek juga membuat pertidaksamaan yang ada pada soal dengan penjelasan yang benar. Subjek mampu menjelaskan strategi yang akan digunakan dengan urut dan jelas. Subjek juga lancar dan tidak kebingungan saat menjelaskan langkah-langkah dari strategi yang akan digunakan. Seperti penelitian oleh 
Laily subjek yang memiliki kecerdasan linguistik tinggi mampu memperkirakan langkah penyelesaian dan menjelaskan secara logis [14]. Subjek mampu menjelaskan proses penyelesaian secara urut dan masuk akal. Subjek menjelaskan dengan lancar. Informasi yang disampaikan tidak sepotong-sepotong serta penyebutan simbol matematika sudah benar. Setiap langkah-langkah penyelesaian juga diberi alasan oleh subjek sehingga sangat mudah dimengerti. Seperti hasil penelitian Ismail dan Mochamad Alfian Mukti Pradana siswa yang memiliki kecerdasan liguistik tinggi mampu mengutarakan pendapatnya dengan jelas secara lisan maupun tulisan [17]. Subjek mampu menjelaskan hasil analisis dan evaluasi strategi lain untuk mengerjakan soal. Subjek dapat menjelaskan kekurangan serta kelebihan dari dua strategi yang telah subjek gunakan untuk menyelesaikan soal.

\section{Kemampuan Komunikasi Matematika Tulis Subjek dengan Kecerdasan Linguistik Sedang (SLS)}

SLS belum mampu menuliskan informasi yang diketahui dan ditanyakan secara jelas pada soal karena informasi yang dituliskan tidak lengkap dan tidak teratur. Namun penulisan kalimat tanya yang ditulis oleh subjek sudah tepat. Sejalan dengan penelitian oleh Lila Ambarwati bahwa siswa dengan kecerdasan linguistik sedang menuliskan informasi dengan tidak lengkap [18]. Subjek belum mampu membuat permisalan matematika dari soal menggunakan simbol-simbol matematika dalam bentuk tulisan ataupun gambar dengan benar, karena subjek tidak membuat permisalan dari soal. Namun subjek sudah menuliskan pertidaksamaan sesuai dengan informasi yang ada pada soal serta menggambar koordinat kartesius dengan benar meskipun kurang rapi. Subjek belum mampu menentukan strategi pengerjaan dengan benar, karena alasan menggunakan strategi yang ditulis tidak menjelaskan pendapat subjek tentang strategi tersebut. Namun subjek benar dalam menentukan strategi yang akan digunakan untuk menyelesaikan soal. Subjek mampu menuliskan proses penyelesaian dengan urut dan jelas. Kesimpulan yang dituliskan oleh subjek juga tepat dan mudah untuk dimengerti. Sejalan dengan pernyataan Nur laili, dkk bahwa subjek dengan kecerdasan linguistik sedang mampu menyajikan hasil dan menjelaskan kesimpulan yang diperoleh dengan baik [16]. Subjek mampu menemukan strategi lain yang dapat digunakan untuk menyelesaikan soal. Subjek juga mampu menuliskan proses penyelesaian dengan urut dan dapat dipahami.

\section{Kemampuan Komunikasi Matematika Lisan Subjek dengan Kecerdasan Linguistik Sedang (SLS)}

SLS mampu menjelaskan informasi yang ada pada soal dengan benar, meskipun saat subjek menjelaskan informasi yang ada pada soal masih terjadi kesalahan pembacaan, namun informasi yang disampaikan sudah benar. Sama seperti pernyataan Nur laili, dkk yaitu subjek dengan kecerdasan linguistik sedang dapat menyebutkan dan menjelaskan informasi yang diketahui dalam soal [16]. Subjek mampu memahami dan menjelaskan bahasa matematika yang ada pada soal serta menyebutkan simbol pertidaksamaan dengan benar. Subjek belum mampu menjelaskan strategi yang akan digunakan dengan jelas, karena penjelasan yang disampaikan terlalu singkat dan rumit. Masih ada penjelasan dari subjek yang sulit dipahami dan kurang lengkap. Subjek mampu menjelaskan proses penyelesaian dengan urut dan masuk akal. Penjelasan informasi yang subjek sampaikan juga sudah benar. Subjek juga langsung menentukan kesimpulan sebelum ditanyakan oleh peneliti.Subjek mampu menjelaskan hasil analisis dan evaluasi strategi lain untuk menyelesaikan soal, karena subjek tidak menjelaskan secara terperinci hasil analisis dan evaluasi dari strategi lain yang digunakan subjek.

\section{Kemampuan Komunikasi Matematika Tulis Subjek dengan Kecerdasan Linguistik Rendah (SLR)}

SLR masih belum mampu menuliskan informasi yang ada pada soal secara jelas, karena informasi yang dituliskan tidak lengkap dan tidak teratur. Penulisan kalimat tanya yang ditulis oleh subjek dengan kecerdasan linguistik rendah sudah tepat. Sejalan dengan pernyataan Lila Ambarwati siswa dengan kecerdasan linguistik rendah dalam tahap memahami masalah 
menuliskan informasi dengan tidak lengkap [18]. Subjek belum mampu membuat permisalan dari informasi yang ada pada soal, namun subjek sudah menuliskan pertidaksamaan sesuai dengan soal. Koordinat kartesius yang digambar oleh subjek sangat jelas dan dapat dipahami. Sejalan dengan Nur laili, dkk yaitu menggambarkan situasi masalah secara visual dan menginterpretasi ide matematika dengan cukup baik [16]. Subjek belum mampu menentukan strategi pengerjaan dengan benar, karena alasan menggunakan cara tersebut tidak menjelaskan pendapat subjek tentang strategi tersebut. Namun benar dalam menentukan strategi yang akan digunakan untuk menyelesaikan soal. Subjek mampu menuliskan proses penyelesaian dengan urut dan jelas. Kesimpulan yang dituliskan juga sudah tepat, sehingga mudah untuk dimengerti. Sejalan dengan Rahmawati, dkk siswa dengan kecerdasan linguistik rendah mampu melakukan operasi hitung dengan benar [15]. Subjek mampu menemukan strategi lain yang dapat digunakan untuk menyelesaikan soal tersebut, meskipun subjek menuliskan proses penyelesaian kurang teratur.

\section{Kemampuan Komunikasi Matematika Lisan Subjek dengan Kecerdasan Linguistik $\operatorname{Rendah}($ SLR)}

SLR mampu menjelaskan informasi yang ada pada soal dengan benar dan jelas, hanya saja subjek sedikit terbata-bata saat menjelaskan informasi yang ada pada soal. Sejalan dengan Rahmawati, dkk siswa dengan kecerdasan linguistik rendah mampu menyebutkan apa yang diketahui dalam soal [15]. Subjek masih belum mampu memahami dan menjelaskan bahasa matematika yang ada pada soal, karena subjek salah dalam menyebutkan simbol pertidaksamaan yang ada pada soal. Subjek masih bingung dalam pemilihan kalimat saat menjelasan bahasa matematika yang ada pada soal. Subjek masih belum mampu menjelaskan strategi yang akan digunakan oleh subjek, karena subjek masih salah menyebutkan langkah-langkah pada soal. Penjelasan dari subjek singkat namun membingungkan. Sesuai dengan hasil penelitian Ismail dan Mochamad Alfian Mukti Pradana dia (siswa yang memiliki kecerdasan liguistik rendah) dapat merencanakan dugaan dan langkah pemecahan masalahnya, tetapi tidak dapat mengutarakan pendapat atau apa yang dipikirkan dengan baik [17]. Subjek mampu menjelaskan proses penyelesaian dari soal dengan benar, hanya saja masih ada kesalahan dalam menyebutkan simbol pertidaksamaan. Kesimpulan yang disebutkan oleh subjek sudah benar. Penjelasan dari subjek singkat dan kurang lancar. Subjek belum mampu menjelaskan hasil analisis dan evaluasi strategi lain yang digunakan untuk menyelesaikan soal. Subjek hanya memberi alasan pribadi, bukan hasil analisis dan evaluasi dari strategi-strategi yang digunakaan untuk menyelesaikan soal.

\section{Kesimpulan}

Berdasarkan hasil dan pembahasan diatas, kemampuan komunikasi matematika tulis dan lisan siswa SMA dalam menyelesaikan soal cerita ditinjau dari kecerdasan linguistik dapat disimpulkan sebagai berikut.

Siswa dengan kecerdasan linguistik tinggi (SLT) mampu menuliskan segala informasi yang ada pada soal dengan lengkap dan lancar. Permisalan, pertidaksamaan dan koordinat kartesius yang dituliskan sudah benar dan jelas. Siswa tidak menjelaskan alasan menggunakan strategi yang ia pilih dengan benar, namun mampu menuliskan proses penyelesaian dengan urut dan jelas. Kesimpulan yang dituliskan sudah tepat. Siswa menuliskan proses penyelesaian strategi lain dengan jelas dan terperinci. Penulisan siswa juga cukup terlihat rapi. Siswa dengan kecerdasan linguistik sedang (SLS) masih kurang dalam menuliskan informasi yang ada pada soal dan tidak membuat permisalan serta belum menjelaskan alasan menggunakan strategi yang ia gunakan dalam menyelesaikan soal. Namun penulisan pertidaksamaan dan gambar koordinat kartesius yang dibuat sudah benar. Siswa juga sudah menuliskan hal yang ditanyakan dengan benar serta menuliskan proses penyelesaian dan kesimpulan dengan urut dan jelas termasuk pada strategi lain yang siswa temukan. Siswa dengan kecerdasan linguistik rendah (SLR) tidak 
lengkap menuliskan informasi yang ada pada soal, tetapi sudah tepat dalam menuliskan hal yang ditanyakan dalam bentuk kalimat tanya. Siswa tidak membuat permisalan dari soal, namun membuat pertidaksamaan dan diagram kartesius dengan baik dan jelas. Siswa tidak menuliskan alasan menggunakan strategi penyelesaian soal dengan benar, namun mampu menuliskan proses penyelesaian serta kesimpulan dengan urut dan jelas. Penulisan proses penyelesaian strategi lain oleh siswa masih kurang teratur.

Siswa dengan kecerdasan linguistik tinggi (SLT) mampu menjelaskan segala informasi serta bahasa matematika yang ada pada soal dengan baik dan jelas. Siswa juga mampu menjelaskan strategi yang akan digunakan serta menjelaskan proses penyelesaian dan kesimpulan dengan baik dan jelas. Siswa juga menjelaskan kelebihan dan kekurangan dari dua strategi yang digunakan oleh siswa untuk menyelesaikan soal. Siswa dengan kecerdasan linguistik sedang (SLS) mampu memahami dan menjelaskan informasi serta bahasa matematika yang ada pada soal dengan baik. Penjelasan siswa mengenai strategi yang akan digunakan masih terdengar rumit dan tidak lengkap, akibatnya sulit untuk dipahami. Proses penyelesaian dan kesimpulan dijelaskan dengan urut dan jelas. Tetapi penjelasan hasil analisis dan evaluasi strategi lain masih kurang terperinci.Siswa dengan kecerdasan linguistik rendah (SLR) mampu menjelaskan informasi pada soal dengan benar meski sedikit terbata-bata. Penyebutan simbol pertidaksamaan masih salah. Siswa juga terlihat kebingungan memilih kata untuk menjelaskan informasi pada soal. Siswa masih salah dalam menjelaskan lagkah-langkah strategi yang akan digunakan untuk menyelesaikan soal, penjelasan dari siswa juga masih membingungkan. Proses penyelesaian dan kesimpulan sudah dijelaskan dengan urut dan benar. Siswa hanya memberi alasan pribadi, bukan hasil analisis dan evaluasi dari strategi-strategi yang digunakaan untuk menyelesaikan soal.

\section{Daftar Pustaka}

[1] NCTM. Curriculum and Evaluation Standars for School Mathematics. USA: The National Council of Teachers of Mathematics, Inc. 2000.

[2] R. Ariawan dan Nufus H.. Hubungan Kemampuan Pemecahan Masalah Matematika dengan Kemampuan Komunikasi Matematika Siswa. Theorems (The Original Research of Mathematics). 2017; 1(2): 82-91, doi: 10.31949/th.v1i2.384.

[3] Citra Utami, dkk. Pembelajaran Model Generatif Dengan Strategi Group Investigation Untuk Meningkatkan Kemampuan Komunikasi Matematika Siswa. Unnes Journal of Mathematics Education Research, UJMER. 2015; 4 (1): 2552-6455.

[4] Siti Zahara Harahap, Izwita Dewi, Ida Karnasih. Peningkatan Kemampuan Penalaran Logis dan Komunikasi Matematika Melalui Model Pembelajaran Kooperatif Tipe Think Pair Share (TPS) di SMP Negeri 24 Medan. Jurnal Pendidikan Matematika Paradikma. 2014; 7(3): 28-47, doi: 10.24114/paradikma.v7i3.2967.

[5] Kemendikbud. Peraturan Menteri Pendidikan dan Kebudayaan Republik Indonesia Nomor 23 Tentang Standar Proses Pendidikan Dasar dan Menengah. Jakarta: Kemendikbud. 2016.

[6] Marsudi Rahardjo dan Astuti Waluyati. Pembelajaran Operasi Hitung Campuran di SD. Yogyakarta: PPPPTK Matematika. 2011.

[7] Mutamimah dan Janet Trinike Manoy. Kemampuan Komunikasi Matematika Siswa SMP dalam Menyelesaikan Soal Cerita Ditinjau dari Tipe Kepribadian. Jurnal MathEdunesa Jurnal Ilmiah Pendidikan Matematika. 2019; 8(3): 576-582, doi: 10.26740/mathedunesa.v8n3.p576-582.

[8] Linda Campbell. Metode Praktis Pembelajaran Berbasis Multiple Intelligences, terj. Tim Intuisi. Depok: Intuisi Press. 2006.

[9] Howard Gardner. Frames of Minds: The Theory of Multiple Intellegence. New York: Basic Book. 2011.

[10] Armstrong, T. Multiple Intelligencess in The Classroom $3^{\text {rd }}$ edition. Virginia: ASCD. 2008.

[11] Suyadi. Psikologi Belajar PAUD. Yogyakarta: PT. Pustaka Insani Madani. 2010. 
[12] Iyan Irvaniyah dan Reza Oktaviana Akbar. Analisis Kecerdasan Logis Matematis dan Kecerdasan Linguistik Siswa Berdasarkan Jenis Kelamin (Studi Kasus Pada Siswa Kelas XI IPA MA Mafatihul Huda). Jurnal EduMa IAIN Syekh Nurjati Cirebon. 2014; 3(1): 138-159, doi: 10.24235/eduma.v3i1.11.

[13] Yanti, Y. R.. Representasi siswa dalam pemecahan masalah SPLDV (Sistem Persamaan Linear Dua Variabel) Berdasarkan Kecerdasan Majemuk. Tesis tidak diterbitkan. Universitas Negeri Surabaya; 2017.

[14] Laily Hidayatur Rohmah. Profil Antisipasi Siswa dalam Memecahkan Masalah Matematika Ditinjau dari Kecerdasan Linguistik dan Kecerdasan Logis-Matematika. Tesis tidak diterbitkan. UIN Sunan Ampel Surabaya; 2017.

[15] Rahmawati, Abdul Rahman, Awi Dassa. Analysis of Mathematical Word Problems Solving Based on Mathematical-Logical Intelligence and Linguistic Intelligence on Twelfth Grade Students of Sman 1 Makassar.Diploma Tesis tidak diterbitkan. Dalam Eprint Universitas Negeri Makassar; 2018.

[16] Nur Laili Mutmainah, Sardulo Gembong, dan Davi Apriandi. Profil Komunikasi Matematika Siswa Sekolah Menengah Pertama dalam Memecahkan Masalah Matematika Ditinjau dari Kecerdasan Linguistik. Jurnal Penelitian LPPM IKIP PGRI Madiun. 2016; 4(2): 129-139.

[17] Mochamad Alfian Mukti Pradana dan Ismail. Profil Antisipasi Siswa dalam Memecahkan Masalah Aljabar Ditinjau dari Kecerdasan Linguistik dan Kecerdasan LogisMatematika. Jurnal MathEdunesa Jurnal Ilmiah Pendidikan Matematika. 2019; 8(3): 559568, doi: 10.26740/mathedunesa.v8n3.p559-568.

[18] Lila Ambarwati dan Rini Setianingsih. Identifikasi Kemampuan Komunikasi Matematika Siswa SMA Kelas XI dalam Pemecahan Masalah Kontekstual Materi Mean Ditinjau dari Kecerdasan Linguistik. Tesis tidak diterbitkan. Universitas Negeri Surabaya; 2016

[19] Yulianto dan Sugeng Sutiarso. Meningkatkan Kemampuan Komunikasi Dan Pemecahan Masalah Dalam Pembelajaran Matematika. PROSIDING Seminar Nasional Matematika dan Pendidikan Matematika UAIN Raden Intan Lampung. 2017; 1(1): 289-295. 